Check for updates

Cite this: RSC Adv., 2019, 9, 2325

\title{
Efficient synthesis of Ibrutinib chiral intermediate in high space-time yield by recombinant $E$. coli co- expressing alcohol dehydrogenase and glucose dehydrogenase $\uparrow$
}

\begin{abstract}
Yitong Chen, Baodi Ma, (D) * Songshuang Cao, Xiaomei Wu and Yi Xu*
The production of (S)-N-boc-3-hydroxy piperidine (NBHP) via asymmetric bioreduction of 1-boc-3piperidinone with reductase is impeded by the need for expensive coenzymes $N A D(P) H$. In order to regenerate the coenzyme in situ, the gene of alcohol dehydrogenase from Thermoanaerobacter brockii and glucose dehydrogenase from Bacillus subtilis were ligated into the multiple cloning sites of pRSFDuet-1 plasmid to construct the recombinant Escherichia BL21 (DE3) that co-expressing alcohol dehydrogenase and glucose dehydrogenase. Different culture conditions including the medium composition, inducer and $\mathrm{pH}$ etc were systematically investigated to improve the enzyme production. The enzyme activity was increased more than 11-fold under optimal culture condition, from 12.7 to 139.8 $U L^{-1}$. In the further work, the asymmetric reduction of 1-boc-3-piperidinone by whole cells of recombinant $E$. coli was systematic optimized to increase the substrate concentration and reaction efficiency. At last, S-NBHP ( $>99 \%$ ee) was prepared at $500 \mathrm{mM}$ substrate concentration without external addition of cofactors. The conversion of S-NBHP reached $96.2 \%$ within merely $3 \mathrm{~h}$, corresponding a high space-time yield around $774 \mathrm{~g} \mathrm{~L}^{-1} \mathrm{~d}^{-1}$. All these results demonstrated the potential of recombinant $E$. coli BL21 (DE3) coupled expressing alcohol dehydrogenase and glucose dehydrogenase for efficient synthesis of S-NBHP.
\end{abstract}

Received 30th September 2018 Accepted 10th January 2019

DOI: 10.1039/c8ra08100j

rsc.li/rsc-advances

\section{Introduction}

Chiral hydroxyl piperidines and their derivatives are of great importance in the pharmaceutical industry and many of them have pharmaceutical activity, such as anti-tumor agents, antibiotics and anti-senile dementia agents. ${ }^{1}$ Many bioactive molecules and active pharmaceutical ingredients (API) contain one or more piperidine rings., ${ }^{2,3}$ Ibrutinib is a targeted anticancer drug that inhibits Bruton tyrosine kinase for the treatment of mantle cell lymphoma. $(S)$ - $N$-boc-3-hydroxy piperidine (NBHP) is a key intermediate in the synthesis of Ibrutinib.

Currently, several approaches have been developed for the synthesis of chiral alcohol, including classic diastereomeric resolution, ${ }^{4}$ asymmetric synthesis, ${ }^{5}$ and asymmetric reduction. ${ }^{6}$ Of these methods, asymmetric bioreduction has attracted extensive attention due to the high stereoselectivity, mild condition and $100 \%$ theoretical yield. Asymmetric bioreduction has been successfully applied in the preparation of $(S)-(4-$ chlorophenyl)-(pyridin-2-yl)methanol, ${ }^{7}$

(R)-1-phenyl-1,2-

School of Chemical and Environmental Engineering, Shanghai Institute of Technology, 100 Haiquan Road, Shanghai 201418, China. E-mail: xuyi@sit.edu.cn; mabaodi2005@163.com

$\dagger$ Electronic supplementary information (ESI) available. See DOI: 10.1039/c8ra08100j ethanediol $^{8}$ and ethyl (R)-4-chloro-3-hydroxybutanoate ${ }^{9}$ etc. However, there were few reports about the synthesis of $(S)-N$ boc-3-hydroxy piperidine (NBHP) via asymmetric bioreduction. Romain Lacheretz et al. ${ }^{10}$ used the tissue of Daucus carota as biocatalyst to reduce 1-boc-3-piperidinone, and moderate chiral purity (ee 95\%) and low yield of product (73\%) was obtained. Other reductases reported to reduce 1-boc-3-piperidinone more efficiently were the alcohol dehydrogenase from Thermoanaerobacter brockii, ${ }^{\mathbf{1 1}}$ and KR-110 screened form a commercial ketoreductase library. ${ }^{\mathbf{1 2}}$ However, expensive exogenous coenzyme has to be added to the reaction system to allow the reaction to proceed.

The expensive cofactor $\mathrm{NAD}(\mathrm{P}) \mathrm{H}$ was required in the bioreduction process, thus its regeneration attracted extensive attention in the last few decades. As early as the 1980s, researchers began to develop different cofactor regeneration systems, including biological (intracellular coenzyme regeneration, substrate coupling method and enzyme coupling method), electrochemical, photochemical and pure chemistry and so on. Currently, enzyme coupling and substrate coupling have been favoured. ${ }^{13,14}$ The reduction of the substrate and the regeneration of the coenzyme are performed by two different enzymes in the double enzyme-coupled system. At present, formate dehydrogenase $(\mathrm{FDH})$ and glucose dehydrogenase 
(GDH) mediated coenzyme regeneration system proved to be feasible in the industrial application. ${ }^{\mathbf{1 5}}$ There are many successful examples using GDH to construct a coenzyme regeneration system. For instance, Gröger et al. had constructed a 'Designer cell' containing GDH from Bacillus subtilis and ADH from Rhodococcus erythropolis, and it had been used for the asymmetric reduction of a variety of aryl ketones in the absence of exogenous coenzyme. ${ }^{\mathbf{1 6 , 1 7}}$ However, no such report on the production of $S$-NBHP was found.

The alcohol dehydrogenase from Thermoanaerobacter brockii (TbADH) was an attractive ADH in the biotechnology due to its high thermostability, excellent activity and enantioselectivity for the reduction of 1-boc-3-piperidinone. ${ }^{\mathbf{1 1}}$ In current research, a novel two-enzyme (ADH and GDH) co-overexpressing system was developed for efficient asymmetric reduction of 1-boc-3piperidinone without needing exogenous coenzyme. The vector pRSFDuet-1 contains two multiple cloning sites and each of them is preceded by a T7 promoter and ribosome binding site. In present work, the gene $\mathrm{TbADH}^{\mathbf{1 8}}$ and glucose dehydrogenase from Bacillus subtilis (BsGDH) ${ }^{19}$ were designed to ligate into the multiple cloning sites (MCS) of vector pRSFDuet-1 and construct a recombinant $E$. coli BL21 (DE3) with both TbADH and BsGDH activity. $S$-NBHP can be prepared via the asymmetric bioreduction of 1-boc-3-piperidine catalyzed by the $\mathrm{TbADH}$ and the coenzyme NADPH can be recycled by the BsGDH and cosubstrate glucose in situ (Scheme 1). The enzyme production and reaction efficiency were further improved via the optimization of microorganism cultivation and reaction condition, respectively.

\section{Experimental}

\subsection{Chemicals}

Starch and yeast power were purchased from Aladdin Industrial Corporation (Shanghai, China). Tryptone was supplied by China National Medicines Co. Ltd. (Beijing, China). Unless otherwise stated, all other chemicals were obtained from commercial sources and were of analytical grade.

\subsection{Strains and culture conditions}

The LB medium was used as seed medium, and the composition was $\left(\mathrm{g} \mathrm{L}^{-1}\right)$ : yeast power 5 ; tryptone 10 ; $\mathrm{NaCl} 10 ; \mathrm{pH}$ 7.0. The fermentation medium was optimized based on LB medium.

Recombinant $E$. coli BL21 (DE3) cells was inoculated into LB medium containing $50 \mathrm{mg} \mathrm{\textrm {L } ^ { - 1 }}$ kanamycin and cultivated at

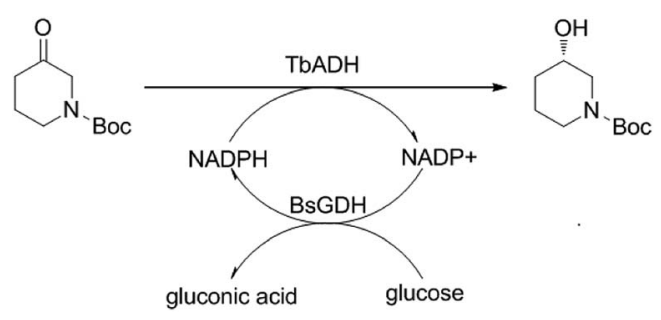

Scheme 1 Asymmetric reduction of 1-boc-3-piperidinone to (S)-Nboc-3-hydroxy piperidine by recombinant $E$. coli with both $\mathrm{TbADH}$ and BsGDH activity.
$37{ }^{\circ} \mathrm{C}$ for $12 \mathrm{~h}$ on a rotary shaker $(200 \mathrm{rpm})$. Then the seed culture was inoculated into $50 \mathrm{~mL}$ fermentation medium containing $50 \mathrm{mg} \mathrm{L}{ }^{-1}$ kanamycin and grown at $37^{\circ} \mathrm{C}$. After $3 \mathrm{~h}$, IPTG was added to the culture with final concentration of $0.025 \mathrm{mM}$, and then the recombinant $E$. coli were continue cultivated at $40{ }^{\circ} \mathrm{C}$ for another $10 \mathrm{~h}$ for protein expression.

\subsection{Construction of co-expression system of TbADH and BSGDH}

The TbADH and BsGDH gene were synthesized by the Generay Biotech (Shanghai) Co., Ltd. The exogenous gene was ligated into the first multi clone site (MCS) via BamH/HindIII restriction sites, and the second MCS via the NdeI/XhoI restriction sites. The construction of recombinant pRSFDuet- 1 plasmid and its transformation into $E$. coli were performed according to standard protocols.

\subsection{Enzyme assay}

To assay the activity of recombinant $E$. coli for reducing 1-boc-3piperidinone, $10 \mathrm{mg}$ of dry cell pellet was suspended in $950 \mu \mathrm{L}$ phosphate buffer ( $\mathrm{pH} 7.0,200 \mathrm{mM}$ ) which contained $0.5 \%$ glucose. The mixture was incubated at $30^{\circ} \mathrm{C}$ and $12000 \mathrm{rpm}$ on thermo-mixer compact (Zuofei Co., China) for $15 \mathrm{~min}$. Then the substrate was added into the mixture with a final concentration of $50 \mathrm{mM}$ and the reaction was carried out for 15 minutes under the same conditions. The sample was extracted twice with equal volume of ethyl acetate. The combined extracts were dried over anhydrous sodium sulfate and analyzed by gas chromatography (GC).

\subsection{Optimization of culture conditions for recombinant $E$. coli BL21 (DE3)}

The media composition and culture condition for recombinant E. coli were optimized through the 'one-factor-at-a-time' ${ }^{20,21}$ The factors of carbon source, nitrogen source, inducer, $\mathrm{pH}$ and temperature were varied in each experiment, and the corresponding cell mass and enzyme activity after cultivation were determined as described above.

\subsection{Asymmetric reduction of $\mathrm{N}$-boc-3-piperidone catalyzed by recombinant $E$. coli co-expressing alcohol dehydrogenase and glucose dehydrogenase}

Whole cell of recombinant $E$. coli was used as biocatalyst in this study. The collected cells were resuspended into the phosphate buffer ( $\mathrm{pH} 7.0,200 \mathrm{mM}$ ) and were incubated at $30^{\circ} \mathrm{C}$ for $15 \mathrm{~min}$. Then, adequate amount of substrate, glucose, and $\mathrm{NADP}^{+}$were added into the suspension. The reaction mixture was incubated at $30{ }^{\circ} \mathrm{C}$ and $12000 \mathrm{rpm}$ on thermo-mixer compact (Zuofei Co., China). The reaction conditions including the initial $\mathrm{pH}$, temperature, co-solvent, the amount of glucose and $\mathrm{NADP}^{+}$were optimized in this research. When the substrate concentration was increased to $500 \mathrm{mM}, \mathrm{Na}_{2} \mathrm{CO}_{3}$ solution $(1 \mathrm{M})$ or ammonia solution ( $5 \mathrm{M}$ ) was added to neutralize the gluconic acid formed during the reaction. 


\subsection{Analytical methods}

The conversion of the sample was analyzed by GC (GC-2010, Shimadzu Co., Japan) equipped with a $\beta$-DEX ${ }^{\mathrm{TM}} 120$ Capillary Column $(30 \mathrm{~m} \times 0.25 \mathrm{~mm} \times 0.25 \mu \mathrm{m}$, Supelco, Sigma-Aldrich Co., USA). The carrier gas is nitrogen, and total flow is 20.0 $\mathrm{mL} \min ^{-1}$. The temperature of detector is set as $280{ }^{\circ} \mathrm{C}$ and injector's temperature is $230{ }^{\circ} \mathrm{C}$. The oven program of the column temperature is as follows: $1 \mathrm{~min}$ at $100{ }^{\circ} \mathrm{C}$, first ramp at $5{ }^{\circ} \mathrm{C} \min ^{-1}$ to $150{ }^{\circ} \mathrm{C}$ (hold for $2 \mathrm{~min}$ ), and second ramp at $2{ }^{\circ} \mathrm{C} \min ^{-1}$ to $160{ }^{\circ} \mathrm{C}$ (hold for $2 \mathrm{~min}$ ). The whole analysis process is 35 minutes. The retention time for 1-boc-3piperidinone and NBHP were $28.9 \mathrm{~min}$ and $30.9 \mathrm{~min}$, respectively.

The ee value of the product was analyzed by HPLC (LC 20AT, Shimadzu Co., Japan) using a chiral OD-H column $(4.6 \mathrm{~mm} \times$ $250 \mathrm{~mm}$, Daicel Co., Japan). The mobile phase was hexane/ isopropanol ( $97: 3$, by vol.). The extracted and dried samples were analyzed at $27{ }^{\circ} \mathrm{C}$ with the flow rate of $0.8 \mathrm{~mL} \mathrm{~min}^{-1}$, and the detection wavelength is $210 \mathrm{~nm}$. The retention time for $S$ and $R$-NBHP were $12.8 \mathrm{~min}$ and $13.9 \mathrm{~min}$, respectively.

\subsection{Preparative synthesis of $S$-NBHP}

The preparative reduction of 1-boc-3-piperidinone was conducted at the substrate concentration of $0.5 \mathrm{M}$ in a $20 \mathrm{ml}$ aqueous buffer system containing $1 \mathrm{~g}$ recombinant $E$. coli. Glucose of $2.7 \mathrm{~g}$ was added for the NADPH regeneration. The reaction was carried out at $50{ }^{\circ} \mathrm{C}$ and ammonia solution $(5 \mathrm{M})$ was periodical added to the reaction system for neutralizing the gluconic acid formed during the reaction. After the substrate was completely converted into product, the reaction mixture was extracted twice with equal volumes of ethyl acetate. Then the organic phase was combined, dried over anhydrous sodium sulphate and then evaporated in vacuum. The obtained yellow liquid was validated based on the chiral HPLC and ${ }^{1} \mathrm{H}$ NMR spectra.

\section{Results and discussion}

\subsection{Construction of the recombinant plasmids co-expressing} alcohol dehydrogenase and glucose dehydrogenase

Two kinds of recombinant pRSFduet-1 with different position of TbADH and BsGDH gene, pRSFduet-1-tbadh-bsgdh and pRSFduet-1-bsgdh-tbadh were constructed (Fig. S1 $\dagger$ ) and transformed into E. coli BL21(DE3). The expression of target protein was induced by addition of $0.1 \mathrm{mM}$ IPTG. The enzyme activity for asymmetric reduction of 1-boc-3-piperidinone was determined as described in 2.4 to compare the efficiencies of these two kinds recombinant $E$. coli and the results were shown in the Table S1 $\uparrow$. Both of the specific activity and activity of recombinant $E$. coli harboring pRSFduet-1-tbadh-bsgdh was inferior to the recombinant $E$. coli harboring pRSFduet-1-bsgdh-tbadh. The enzymes expression of the recombinant $E$. coli harboring pRSFduet-1-bsgdh-tbadh was further verified by SDS-PAGE (as shown in Fig. S2 $\dagger$ ), and the results showed that both $\mathrm{TbADH}$ and BsGDH expressed as soluble proteins. Therefore, the recombinant $E$. coli harboring pRSFduet-1-bsgdh-tbadh was used in the subsequent study.

\subsection{Optimization of culture conditions}

3.2.1 Effect of carbon source on cell growth and enzyme production. Different carbon sources were selected to substitute the yeast in LB medium. Cell biomass and enzyme activity after cultivation on various medium were determined to evaluate the effect of carbon sources. As shown in Fig. 1A, when the starch was used as carbon source, enzyme activity was superior to that of other carbon source. In addition, the price of starch is cheap.

The concentration of starch was optimized in further work and the results revealed that the most appropriate concentration is $30 \mathrm{~g} \mathrm{~L}^{-1}$, and the activity is $98.4 \mathrm{U} \mathrm{L}^{-1}$ (Fig. 1B). With the increase of starch concentration, the cell mass is increasing, however a decrease of activity was observed when the starch concentration exceed $30 \mathrm{~g} \mathrm{~L}^{-1}$. This may be due to the fact that something from sugar metabolism affects the enzyme production at high sugar concentration.

3.2.2 Effect of nitrogen source on cell growth and enzyme production. Nitrogen source is another important factor affecting cell growth and enzyme production. The commonly used nitrogen sources including inorganic and organic nitrogen were tested and the results are shown in Fig. 2A. Generally, the organic nitrogen is better than inorganic nitrogen. Among the
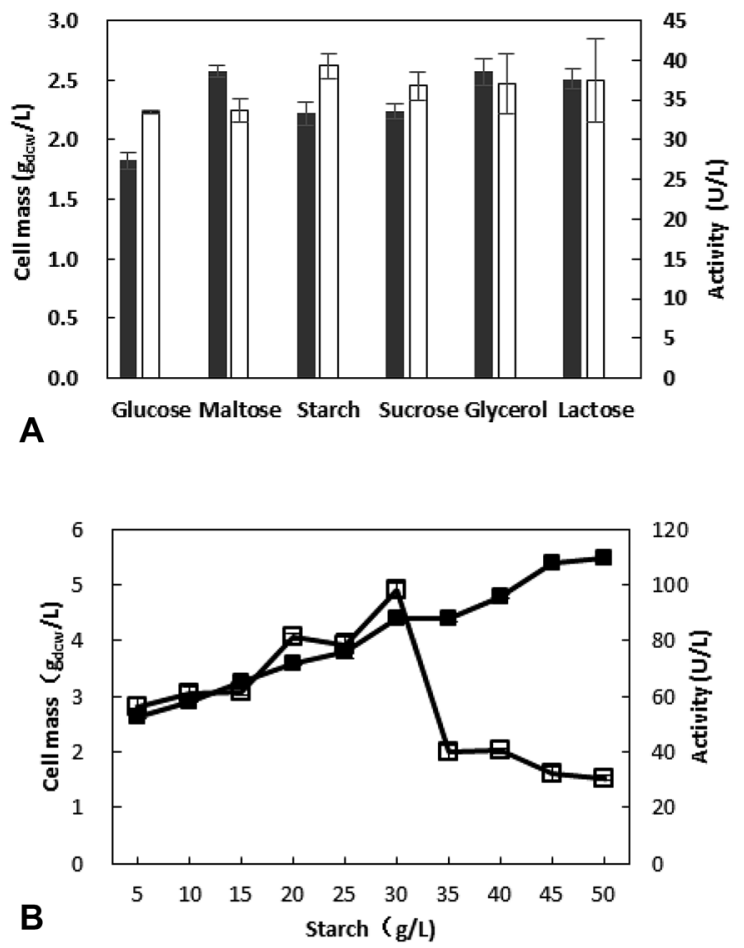

Fig. 1 Effect of carbon source (A) and its concentration (B) on cell mass ( $\square$ ) and enzyme activity ( $\square$ ). (A). Different carbon source were added into the medium. The recombinant $E$. coli was cultivated at the medium with different carbon source. After inoculation at $37^{\circ} \mathrm{C}$ for $2 \mathrm{~h}$, IPTG $(0.1 \mathrm{mM})$ was added, and then cultivated at $30^{\circ} \mathrm{C}$ for $12 \mathrm{~h}$. (B). The recombinant $E$. coli was cultivated at the medium with different starch concentration. After inoculation at $37^{\circ} \mathrm{C}$ for $2 \mathrm{~h}$, IPTG $(0.1 \mathrm{mM})$ was added, and then cultivated at $30^{\circ} \mathrm{C}$ for $12 \mathrm{~h}$. 

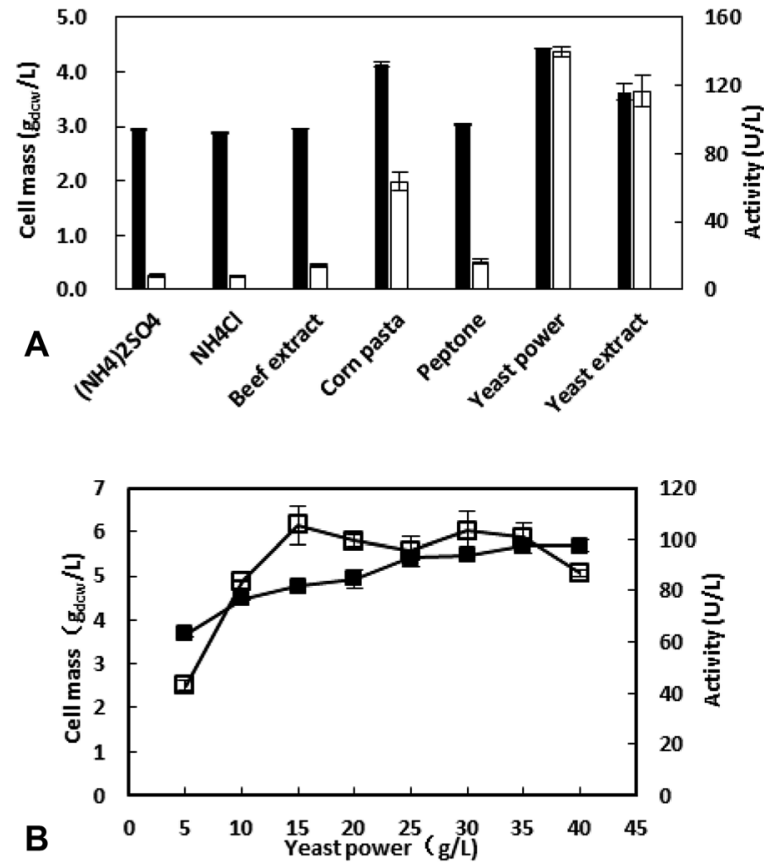

Fig. 2 Effect of nitrogen source (A) and its concentration (B) on cell mass ( $\square$ ) and enzyme activity ( $\square$ ). (A). The recombinant $E$. coli was cultivated at the medium with different nitrogen source. After inoculation at $37^{\circ} \mathrm{C}$ for $2 \mathrm{~h}$, IPTG $(0.1 \mathrm{mM})$ was added, and then cultivated at $30{ }^{\circ} \mathrm{C}$ for $12 \mathrm{~h}$. (B). The recombinant $E$. coli was cultivated the medium with different nitrogen concentration. After inoculation at $37^{\circ} \mathrm{C}$ for $2 \mathrm{~h}$, IPTG $(0.1 \mathrm{mM})$ was added, and then cultivated at $30^{\circ} \mathrm{C}$ for $12 \mathrm{~h}$.

organic nitrogen, yeast power is the best choice. It not only promotes cell growth, but also increases enzyme activity.

The concentration of yeast power was further investigated and the results showed that the appropriate concentration is $15 \mathrm{~g} \mathrm{~L}^{-1}$ with the highest enzyme activity of $105.4 \mathrm{U} \mathrm{L}^{-1}$. Although the amount of cells increased with the increasing of nitrogen source concentration, the metabolites of amino acids could inhibit the expression of the target protein when the concentration $>15 \mathrm{~g} \mathrm{~L}^{-1}$.

3.2.3 Effect of induction conditions on cell growth and enzyme production. Both of the recombinant alcohol dehydrogenase and glucose dehydrogenase are under the control of T7 promoter, which can be induced by IPTG. The incubation time before IPTG added is of significant to the growth and enzyme production of recombinant $E$. coli BL21. ${ }^{22}$ The recombinant $E$. coli BL21 was cultivated at $37^{\circ} \mathrm{C}$, and IPTG of $1 \mathrm{mM}$ was added after incubation for $0-5 \mathrm{~h}$. After incubation at $30{ }^{\circ} \mathrm{C}$ for another $10 \mathrm{~h}$, the enzyme activity and cell mass were determined and the results were shown in Fig. 3A. The highest enzyme activity was obtained when IPTG was added after inoculation at $37^{\circ} \mathrm{C}$ for $3 \mathrm{~h}$.

IPTG with exorbitant concentrations might affect the growth of $E$. coli BL21 (DE3), ${ }^{23}$ and the price of IPTG is expansive. Thus, IPTG with concentrations ranging from 0 to $1 \mathrm{mM}$ were investigated and the results were shown in Fig. 3B. Between 0.1 to $1 \mathrm{mM}$, enzyme activity was similar. When IPTG concentration decreased to $0.025 \mathrm{mM}$, enzyme activity grows to $90.7 \mathrm{U} \mathrm{L}^{-1}$.
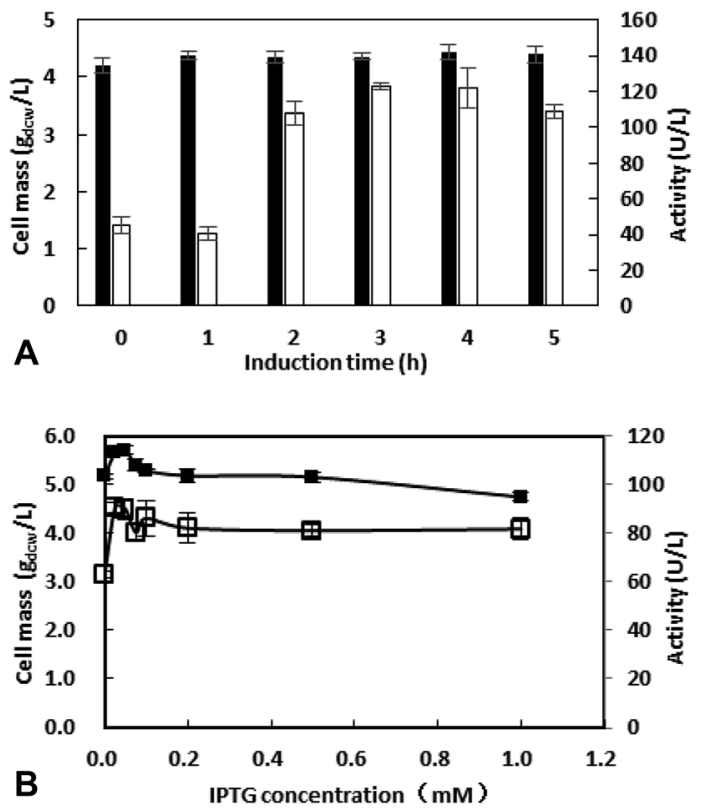

Fig. 3 Effect of induction time (A) and induction concentration (B) on cell mass ( $\square$ ) and enzyme activity ( $\square$ ). (A). Medium cultivated at $37^{\circ} \mathrm{C}$, $200 \mathrm{rpm}$ for $0-5 \mathrm{~h}$, then IPTG $(0.1 \mathrm{mM})$ was added, cultivated at $30^{\circ} \mathrm{C}$, $200 \mathrm{rpm}$ for $10 \mathrm{~h}$. (B). Medium cultivated at $37^{\circ} \mathrm{C}, 200 \mathrm{rpm}$ for $3 \mathrm{~h}$, then different concentrations of induction was added, cultivated at $30^{\circ} \mathrm{C}$, $200 \mathrm{rpm}$ for $10 \mathrm{~h}$.

Thus, the IPTG of $0.025 \mathrm{mM}$ was added after inoculation for $3 \mathrm{~h}$ in the subsequent work.

3.2.4 Effect of pH on cell growth and enzyme production. The effect of initial $\mathrm{pH}$ on cell growth and enzyme production of recombinant $E$. coli was examined with different initial $\mathrm{pH}$ ranging from 4.0 to 9.0 (Fig. 4A). The $\mathrm{pH}$ of the medium was adjusted to the desired value at the beginning using phosphoric acid or NaOH solution. Both the cells mass $\left(5.3 \mathrm{~g}_{\mathrm{dcw}} \mathrm{L}^{-1}\right)$ and specific activity $\left(18.1 \mathrm{U} \mathrm{g}^{-1}\right)$ reached the peak when the initial $\mathrm{pH}$ was adjusted to 6.0. As a result, an initial $\mathrm{pH}$ of 6.0 was used for further study.

3.2.5 Effect of induced temperature on cell growth and enzyme production. Temperature plays a non-negligible role during the protein expression. On the one hand, the cell growth is slow at low temperature. On the other hand, protein may be expressed as inclusion body at high temperate. ${ }^{24}$ For exploring the optimal induce temperature, recombinant $E$. coli was cultivated at different temperature $(20,25,30,35,40,45$ and 50 ${ }^{\circ} \mathrm{C}$ ) after the addition of IPTG. As shown in Fig. 4B, enzyme activity is more sensitive to the temperature compared to cell mass. Both cell mass and enzyme activity reached the peak at $40{ }^{\circ} \mathrm{C}$.

3.2.6 Enzymatic synthesis of $(S)$ - $N$-boc-3-hydroxy piperidine by whole cells cultivated in optimized media and LB media. After optimization, the enzyme activity and cell mass reached $139.8 \mathrm{U} \mathrm{L}^{-1}$ and $6.6 \mathrm{~g}_{\mathrm{dcw}} \mathrm{L}^{-1}$, which were approximately 11 times and 3.6 times of the original activity and cell mass, respectively. The performance of converting the substrate 1-boc3-piperidinone into $S$-NBHP by the whole cell cultured in the initial medium or optimized medium were compared and the 

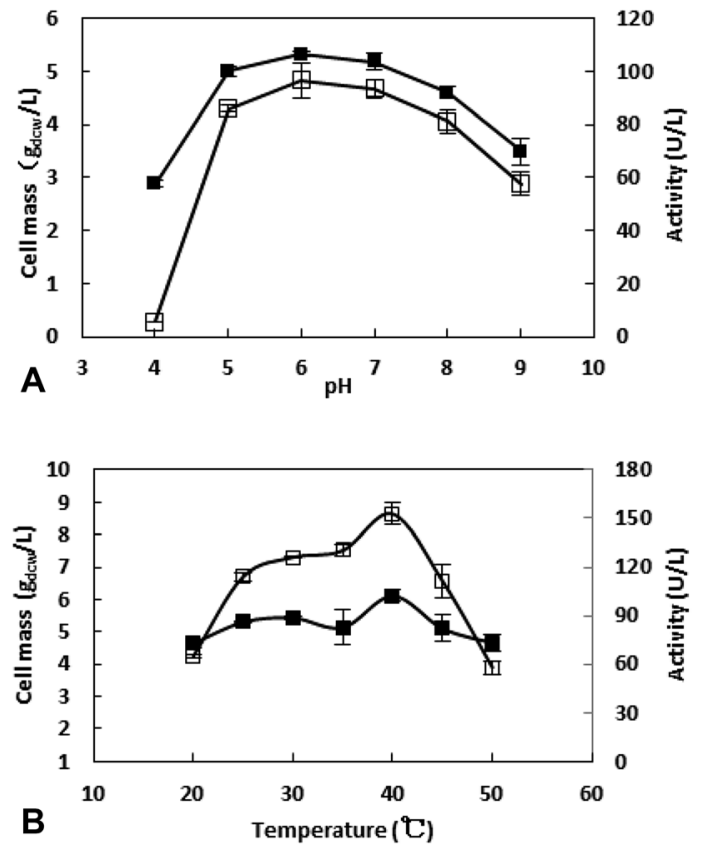

Fig. 4 Effect of $\mathrm{pH}(\mathrm{A})$ and temperature (B) on cell mass ( $\boldsymbol{\square})$ and enzyme activity ( $\square$ ). (A). Medium adjusted its initial $\mathrm{pH}(4.0 \sim 9.0)$ cultivated at $37^{\circ} \mathrm{C}, 200 \mathrm{rpm}$ for $3 \mathrm{~h}$, then $0.025 \mathrm{mM}$ IPTG was added, cultivated at $30^{\circ} \mathrm{C}, 200 \mathrm{rpm}$ for $10 \mathrm{~h}$. (B). Medium cultivated at $37^{\circ} \mathrm{C}$, $200 \mathrm{rpm}$ for $3 \mathrm{~h}$, then $0.025 \mathrm{mM}$ IPTG was added, cultivated in various temperature $\left(20-50{ }^{\circ} \mathrm{C}\right), 200 \mathrm{rpm}$ for $10 \mathrm{~h}$, and the enzyme activity was measured in $200 \mathrm{mM}$ sodium phosphate buffer (pH 6.0).

results were shown in Fig. 5. Using the cells cultivated in optimized medium as catalysts, the substrate 1-boc-3-piperidinone of $50 \mathrm{mM}$ was almost entirely converted after $8 \mathrm{~h}$, and the conversion reached $95 \%$. However, the conversion of reaction catalyzed by cells cultivated in LB medium is only $56 \%$ after $8 \mathrm{~h}$.

\subsection{Optimization of enzymatic asymmetric reduction of 1- boc-3-piperidinone}

3.3.1 Effect of initial $\mathrm{pH}$ on the conversion of 1-boc-3piperidone. The $\mathrm{N}$-boc-3-piperidone was reduced at various $\mathrm{pH}$, ranging from 6 to 10 , and the conversion after $10 \mathrm{~h}$ was measured to investigate the effects of $\mathrm{pH}$ on asymmetric

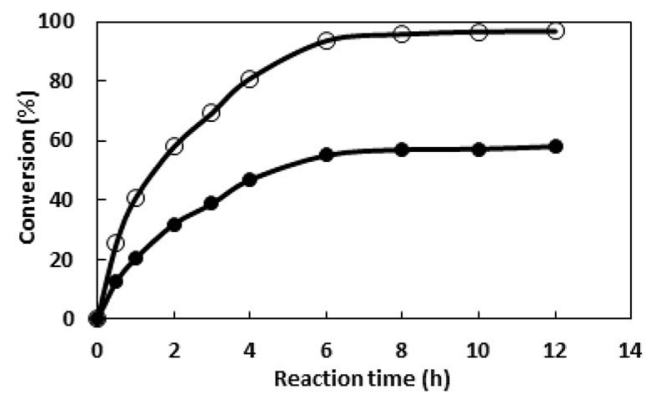

Fig. 5 Enzymatic reduction of 1-boc-3-piperidinone by whole cells cultured in the initial medium $(\mathbf{0})$ or optimized medium $(O)$. A reaction mixture consisting dry cell of $30 \mathrm{~g} \mathrm{~L}^{-1}$ and $50 \mathrm{mM}$ substrate in $0.2 \mathrm{M}$ phosphate buffer ( $\mathrm{pH} 7.0$ ) was incubated at $30^{\circ} \mathrm{C}$ and $200 \mathrm{rpm}$. Sample was taken at different time and the conversion was determined by GC.
Table 1 Effect of initial $\mathrm{pH}$ on the conversion of $\mathrm{N}$-boc-3-piperidone ${ }^{a}$

\begin{tabular}{lcl}
\hline Buffer & pH & Conversion (\%) \\
\hline PBS & 6 & $52.5 \pm 2.8$ \\
& 7 & $76.3 \pm 1.8$ \\
Tris-HCl & 8 & $86.2 \pm 0.1$ \\
& 8 & $73.4 \pm 0.1$ \\
Gly-NaOH & 9 & $74.6 \pm 0.1$ \\
& 9 & $70.4 \pm 0.2$ \\
& 10 & $56.4 \pm 0.2$
\end{tabular}

${ }^{a}$ The collected cells were resuspended into the following buffers (final concentration, $200 \mathrm{mM}$ ): sodium phosphate (pH 6-8) and Tris-HCl (pH 8-9) and Gly-NaOH (pH 9-10). The suspension was incubated at $30{ }^{\circ} \mathrm{C}, 1000 \mathrm{rpm}$ in thermo shaker for $15 \mathrm{~min}$, and then added the substrate and glucose with a final concentration of $50 \mathrm{mM}$. The reaction was carried out at $30{ }^{\circ} \mathrm{C}$ for $10 \mathrm{~h}$.

reduction. As shown in Table 1, the highest conversion was obtained at the $\mathrm{pH} 8.0$ in the PBS buffer. At acid or alkali solution, the whole cell biocatalysts exhibited lower catalytic efficiency.

3.3.2 Effects of organic solvent types and the amount of their addition on the conversion of 1-boc-3-piperidone. The substrate 1-boc-3-piperidinone is not uniformly distributed in the aqueous phase. The addition of co-solvent into the reaction system is an efficient method to increase the solubility of the substrate. However, organic solvents always destroy the cell membrane or affect the enzyme activity. In the following work, different organic solvents with various concentrations were added into the reaction system and the conversion was measured to choose optimal co-solvent. Compared to the conversion (51\%) in the reaction without co-solvent, a relative low conversion $(<10 \%)$ was observed when the dimethyl sulfoxide used as co-solvent (Table 2), indicating the poor incompatibility of dimethyl sulfoxide. Similar conversions were obtained when the methanol and acetonitrile at the concentration of $5 \%(\mathrm{v} / \mathrm{v})$ were used as co-solvent, $80.1 \%$ and $83.1 \%$, respectively. However, the methanol is obviously superior to acetonitrile when the concentration $>10 \%(\mathrm{v} / \mathrm{v})$, indicating the great tolerance of this enzyme towards methanol. Thus, the methanol was chosen as the co-solvent in the subsequent work.

3.3.3 Effects of glucose on the conversion of 1-boc-3piperidone. Glucose acts as co-substrate to regenerate the

Table 2 Effects of organic solvents towards the conversion of $\mathrm{N}$-boc3-piperidone ${ }^{a}$

\begin{tabular}{lrrrr}
\hline & \multicolumn{1}{c}{$5 \%$} & \multicolumn{1}{c}{$10 \%$} & \multicolumn{1}{c}{$15 \%$} & \multicolumn{1}{c}{$20 \%$} \\
\hline Methanol & $80.1 \pm 0.1$ & $75.2 \pm 0.2$ & $68.7 \pm 1.9$ & $67.0 \pm 2.4$ \\
Isopropyl alcohol & $47.8 \pm 2.5$ & $21.4 \pm 0.8$ & $10.9 \pm 0.3$ & $6.3 \pm 1.0$ \\
Acetonitrile & $83.1 \pm 0.5$ & $46.4 \pm 1.1$ & $45.5 \pm 0.8$ & $2.5 \pm 1.4$ \\
Dimethyl sulfoxide & $9.7 \pm 0.5$ & $8.1 \pm 0.4$ & $7.4 \pm 0.4$ & $7.4 \pm 0.4$
\end{tabular}

${ }^{a}$ The collected cells were resuspended into PBS buffer (pH 8.0, 200 $\mathrm{mM}$ ). The suspension was incubated at $30{ }^{\circ} \mathrm{C}, 1000 \mathrm{rpm}$ in thermo shaker for $15 \mathrm{~min}$, and then added the substrate and glucose with a final concentration of $50 \mathrm{mM}$. Various organic solvent were added into the reaction mixture with different final concentration $(5 \%, 10 \%$, $15 \%$ and $20 \%$ ). The reaction was carried out at $30{ }^{\circ} \mathrm{C}$ for $10 \mathrm{~h}$. 
Table 3 Effects of glucose concentration on the conversion of $\mathrm{N}$ boc-3-piperidone $^{a}$

\begin{tabular}{lll}
\hline Glucose $(\mathrm{mM})$ & Glucose/substrate $(n: n)$ & Conversion $(\%)$ \\
\hline 25 & 0.5 & $55.7 \pm 4.3$ \\
50 & 1.0 & $86.4 \pm 0.4$ \\
75 & 1.5 & $91.1 \pm 2.3$ \\
100 & 2.0 & $93.1 \pm 0.9$ \\
125 & 2.5 & $94.4 \pm 1.8$
\end{tabular}

${ }^{a}$ Reaction condition: the collected cells were resuspended into PBS buffer $(\mathrm{pH} 8.0,200 \mathrm{mM})$. The suspension was incubated at $30{ }^{\circ} \mathrm{C}$, $1000 \mathrm{rpm}$ in thermo shaker for $15 \mathrm{~min}$, and then added the substrate (final concentration $50 \mathrm{mM}$ ) and glucose (final concentration of 25 , $50,75,100$ and $125 \mathrm{mM})$. Methanol of $5 \%(\mathrm{v} / \mathrm{v})$ was used as the cosolvent. The reaction was carried out at $30{ }^{\circ} \mathrm{C}$ for $10 \mathrm{~h}$.

NADPH by offering a molecule of $[\mathrm{H}]$ to $\mathrm{NADP}^{+}$catalysed by the GDH. However, the formed gluconic acid would result in the decrease of $\mathrm{pH}$ in reaction system. Various amounts of glucose were added into the reaction system, and the results showed that the conversion was increased obviously with the increase of the glucose amount. When the equivalent ratio was 1.5 , the conversion reached $91 \%$. However, the increase of conversion was not significant with further increase of glucose amount beyond 1.5 times to substrate. The amount of the co-substrate is determined to be 1.5 equivalents to substrate in the subsequent study (Table 3 ).

3.3.4 Effects of temperature on the conversion of 1-boc-3piperidone. Enzymatic reactions usually have an optimum temperature. On the one hand, the reaction speed is faster at higher temperature. On the other hand, the temperature which is too high will lead to protein inactivation.

The bioreduction catalyzed by the recombinant $E$. coli was conducted at temperatures from 30 to $70{ }^{\circ} \mathrm{C}$ to investigate the effect of temperature. As shown in the Fig. 6, the conversion reached $96 \%$ after $10 \mathrm{~h}$ when the temperature was $30{ }^{\circ} \mathrm{C}$. As the temperature increase, the reaction velocity increased gradually. At $50{ }^{\circ} \mathrm{C}$, the conversion reached to $97.8 \%$ after $2 \mathrm{~h}$, but as the temperature continues to rising, the reaction speed is reduced, which may be due to the enzyme inactivation. At $70{ }^{\circ} \mathrm{C}$, the substrate was not converted (data no shown), and the enzyme may have been completely inactivated. The reaction was determined to be conducted at $50{ }^{\circ} \mathrm{C}$ in the subsequent work.

3.3.5 Asymmetric reduction of 1-boc-3-piperidinone by the recombinant $\boldsymbol{E}$. coli with different catalyst loading. The asymmetric reduction of $N$-boc-3-piperidone with different cell load was conducted without the addition of coenzyme, and the substrate concentration was increased to $500 \mathrm{mM}$. As shown in Fig. 7, the conversion reached $29.8 \%, 95.5 \%, 98.4 \%$ at $24 \mathrm{~h}$ when the cell load was $10,30,50 \mathrm{~g} \mathrm{~L}^{-1}$, respectively. A faster bioreduction was achieved when the cell load was increased, which is attributed to the increase of both catalysts and internal cofactors $\mathrm{NADP}^{+}$from the recombinant E. coli. Actually, the conversion reached $96.2 \%$ within merely $3 \mathrm{~h}$ when the cell load was increased to $50 \mathrm{~g} \mathrm{~L}^{-1}$, representing a relatively highspacetime yield (STY, $774 \mathrm{~g} \mathrm{~L}^{-1} \mathrm{~d}^{-1}$ ) for $S$-NBHP. The highest STY

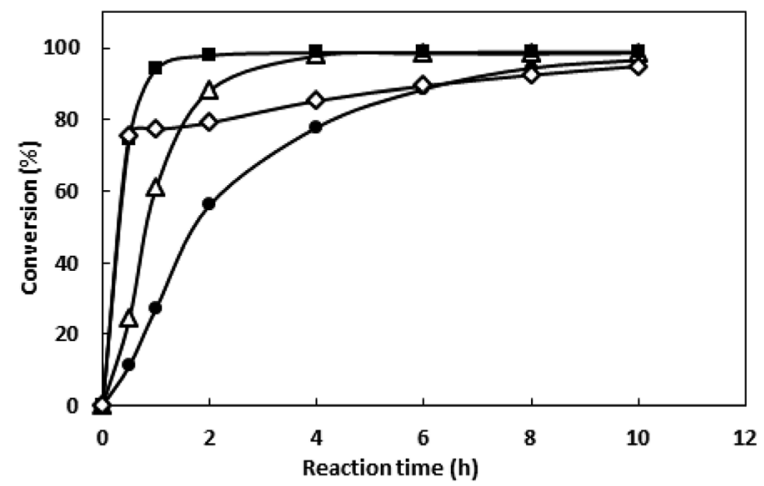

Fig. 6 Effect of temperature on the conversion of $\mathrm{N}$-boc-3-piperidone. The collected cells were resuspended into PBS buffer $(\mathrm{pH} 8.0$, $200 \mathrm{mM}$ ). The suspension was incubated at $30^{\circ} \mathrm{C}, 1000 \mathrm{rpm}$ in thermo shaker for $15 \mathrm{~min}$, and then added the substrate (final concentration of $50 \mathrm{mM}$ ) and glucose (final concentration of $75 \mathrm{mM}$ ). Methanol of $5 \%$ (v/ v) was used as the co-solvent. The reaction was carried out at various temperatures ( 30; $\triangle 40 ; \quad 50$ and $\diamond 60^{\circ} \mathrm{C}$ ) for $10 \mathrm{~h}$. Sample was taken at different time and the conversion was determined by GC.

reported for $S$-NBHP was $552 \mathrm{~g} \mathrm{~L}^{-1} \mathrm{~d}^{-1}$ using the commercial ketone reductase as catalyst and extra glucose dehydrogenase was added to regenerate the coenzyme in this process. ${ }^{25}$

\subsection{Asymmetric reduction of 1-boc-3-piperidinone in preparative scale}

Finally, the asymmetric reduction of $N$-boc-3-piperidone was conducted at preparative-scale (see Section 2.8 for details). Optically pure $S$-NBHP of $1.67 \mathrm{~g}$ was recovered in a total yield of

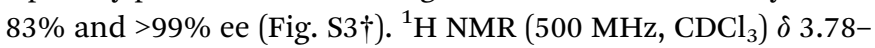
$3.81(\mathrm{~m}, 1 \mathrm{H}), 3.71(\mathrm{~s}, 1 \mathrm{H}), 3.58(\mathrm{~s}, 1 \mathrm{H}), 3.01-3.06(\mathrm{~m}, 1 \mathrm{H}), 2.99$ (dd, $J=12.7,8.0 \mathrm{~Hz}, 1 \mathrm{H}), 2.74(\mathrm{~s}, 1 \mathrm{H}), 1.90(\mathrm{~s}, 1 \mathrm{H}), 1.75-1.77(\mathrm{~m}$, $1 \mathrm{H}), 1.45$ (s, 11H).

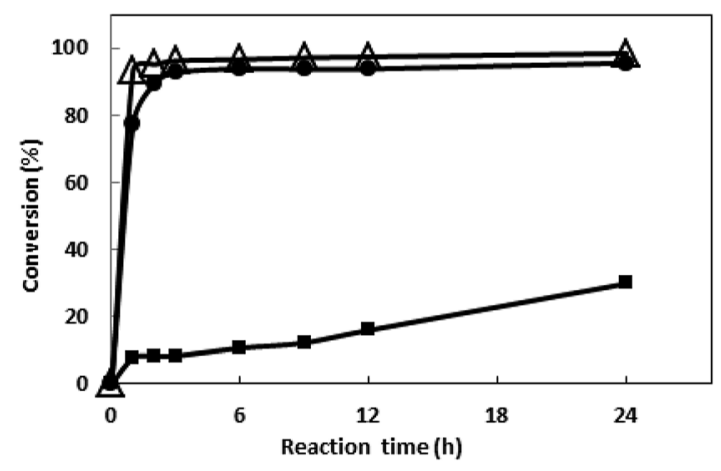

Fig. 7 Asymmetric reduction of 1-boc-3-piperidinone by E. coli BL21 harboring pRSFDuet-bsgdh-tbadh with different cell concentration. The collected cells were resuspended into PBS buffer ( $\mathrm{pH} 8.0,200$ $\mathrm{mM}$ ) with various concentration ( 10 ; 30 ; and $\triangle 50 \mathrm{~g} \mathrm{~L}^{-1}$ ). The suspension was incubated at $30^{\circ} \mathrm{C}, 200 \mathrm{rpm}$ in a shaker for $15 \mathrm{~min}$, and then added the substrate (final concentration $500 \mathrm{mM}$ ) and glucose (final concentration of $750 \mathrm{mM}$ ). Methanol of $5 \%(\mathrm{v} / \mathrm{v})$ was used as the co-solvent. The reaction was carried out at $50{ }^{\circ} \mathrm{C}$ for $24 \mathrm{~h}$. Ammonia solution (5 M) was periodical added to the reaction system for neutralizing the produced acid during the reaction. Samples were taken at different time and the conversion was determined by GC. 


\section{Conclusions}

A recombinant $E$. coli BL21 (DE3) was constructed for coexpressing alcohol dehydrogenase and glucose dehydrogenase using the plasmid pRSFduet-1, which contains two multiple clone sites. The application potential of the constructed recombinant $E$. coli harbouring pRSFduet-1-bsgdh-tbadh was further improved through the optimization of the enzyme production condition and reaction condition. Finally, the bioreduction catalyzed by the recombinant $E$. coli was conducted at the substrate concentration of $500 \mathrm{mM}$ without external addition of cofactors, giving satisfactory conversion (96.2\%) and enantiomeric excesses for $S$-NBHP (ee value $>99 \%$ ). The STY reported in this study (774 $\mathrm{g} \mathrm{L}^{-1} \mathrm{~d}^{-1}$ ) was the highest reported for $S$-NBHP preparation so far. $S$-NBHP was obtained in a preparative experiment in $83 \%$ isolated yield and $99 \%$ ee value. Thus, the recombinant $E$. coli harbouring pRSFduet-1$b s g d h$-tbadh was competitive and promising compared to other biocatalysts for asymmetrically reducing 1-boc-3-piperidinone. Further work about the immobilization of this recombinant $E$. coli and optimization of the reaction for large scale preparation is in the progress.

\section{Conflicts of interest}

There are no conflicts to declare.

\section{Acknowledgements}

This work was financially supported by Shanghai Collaborative Innovation Center of Fragrance, Flavor and Cosmetics (1021ZK170004002), the Shanghai Institute of Technology (YJ2015-36) and Shanghai Municipal Education Commission (ZZyyx15011).

\section{References}

1 Y. Chen, Y. Xu and J. B. Chen, MATEC Web Conf., 2015, 22, 15.

2 I. Dragutan, V. Dragutan and A. Demonceau, RSC Adv., 2012, 2, 719-736.

3 T. J. Harrison, B. O. Patrick and G. R. Dake, Org. Lett., 2007, 9, 367-370.

4 W. Y. Shen, Z. C. Shen, Z. Hu, Y. L. Lin and J. M. Wang, Chin. J. Pharm., 2013, 44, 436-437.

5 M. S. Reddy, M. Narender and K. R. Rao, Tetrahedron, 2007, 63, 331-336.
6 G. W. Zheng, H. L. Yu, J. D. Zhang and J. H. Xu, Adv. Synth. Catal., 2009, 351, 405-414.

7 Y. Ni, J. Y. Zhou and Z. H. Sun, Process Biochem., 2012, 47, 1042-1048.

8 X. T. Zhou, R. Z. Zhang, Y. Xu, H. B. Liang, J. W. Jiang and R. Xiao, Process Biochem., 2015, 50, 1807-1813.

9 Q. Y. Wang, T. T. Ye, Z. Z. Ma, R. Chen, T. Xie and X. P. Yin, J. Ind. Microbiol. Biotechnol., 2014, 41, 1609-1616.

10 R. Lacheretz, D. G. Pardo and J. Cossy, Org. Lett., 2009, 11, 1245-1248.

11 Z. T. Sun, R. Lonsdale, A. Ilie, G. Li, J. Zhou and M. T. Reetz, ACS Catal., 2016, 6, 1598-1605.

12 X. Ju, Y. Y. Tang, X. L. Liang, M. Q. Hou, Z. H. Wan and J. H. Tao, Org. Process Res. Dev., 2014, 18, 827-830.

13 H. M. Zhao and V. D. D. WA, Curr. Opin. Biotechnol., 2003, 14, 583-589.

14 F. Hollmann and A. Schmid, Biocatal. Biotransform., 2004, 22, 63-88.

15 G. W. Huisman, J. Liang and A. Krebber, Curr. Opin. Chem. Biol., 2010, 14, 122-129.

16 M. Kataoka, L. P. S. Rohani, M. Wada, K. Kita, H. Yanase, I. Urabe and S. Shimizu, Biosci., Biotechnol., Biochem., 1998, 62, 167-169.

17 H. Gröger, F. Chamouleau, N. Orologas, C. Rollmann, K. Drauz, W. Hummel, A. Weckbecker and O. May, Angew. Chem., Int. Ed., 2006, 45, 5677-5681.

18 M. Peretz, O. Bogin, S. Tel-Or, A. Cohen, G. Li, J. S. Chen and Y. Burstein, Anaerobe, 1997, 3, 259-270.

19 K. Yamane, M. Kumano and K. Kurita, Microbiology, 1996, 142, 3047-3056.

20 A. Banerjee, P. Kaul and U. C. Banerjee, Appl. Microbiol. Biotechnol., 2006, 72, 77-87.

21 A. K. Khandelwal, V. K. Nigam, M. K. Mohan, P. Ghoshand and B. Choudhury, J. Chem. Technol. Biotechnol., 2007, 82, 645-651.

22 J. F. Liu, Z. J. Zhang, A. T. Li, J. Pan and J. H. Xu, Appl. Microbiol. Biotechnol., 2011, 89, 665-672.

23 P. Dvorak, L. Chrast, P. I. Nikel, R. Fedr, K. Soucek, M. Sedlackova, R. Chaloupkova, V. Lorenzo, Z. Prokop and J. D. Dvorak, Microb. Cell Fact., 2015, 14, 201-215.

24 X. Wu, X. D. Gou and X. J. Chen, Process Biochem., 2015, 50, 104-110.

25 W. Zhu, B. Wang, Q. P. Zhang, H. Wu and B. H. Li, CN Patent 104059952 A, Syncozymes (Shanghai) Co., Ltd., 2014. 